\title{
Floodplain conflicts: regulation and negotiation
}

\author{
J. Pardoe, E. Penning-Rowsell, and S. Tunstall \\ Flood Hazard Research Centre, Middlesex University, London, UK \\ Received: 27 April 2011 - Revised: 15 July 2011 - Accepted: 20 July 2011 - Published: 28 October 2011
}

\begin{abstract}
In the continuing shift from engineered solutions towards more holistic methods of managing flood risk, spatial planning has become the primary focus of a conflict between land and water, water and people. In attempting to strike a balance between making space for water and making space for people, compromises are required. Through five case studies in the UK, this paper analyses the effectiveness of Planning Policy Statement 25 (PPS 25) and the processes of negotiation that it promotes. This assessment allows us to draw conclusions on the nature of the compromises this kind of negotiation can achieve and the implications of this for flood risk management. What emerges is that the beneficial impacts of decisions to develop floodplain areas are given a proper hearing and sensible conditions imposed, rather than arguments to prevent such development remaining unchallenged.
\end{abstract}

\section{Introduction: choices, conflicts and negotiation}

Decisions about floodplains embody a conflict between land and water, water and people. These conflicts are highly complex and efforts to achieve a balance between competing and often irreconcilable or incompatible uses demonstrate a variety of different decision processes, solutions and the embedded values that they represent.

At its most basic, the issue is simple: the use of all land in countries such as the UK is contested, because the country is crowded, different interest groups have different aspirations and the availability of land or space is an essential ingredient for achieving many of their goals. Floodplain areas are no exception to this, and indeed are often contested, as there are several different and competing uses for what appear to many people to be unused spaces ready for some possible new use

Correspondence to: J. Pardoe

(j.pardoe@mdx.co.uk) or development. So we have to choose and as Green and Penning-Rowsell (1999, p. 153) have written, “... choice is conflict, (so) decision making is necessarily about conflict resolution. Choices are necessary because the options are mutually exclusive".

Traditional approaches towards managing flooding have focused only on the conflict between water and people by employing technical measures that physically separate the two (Reiner Böhm et al., 2004). But such structural solutions on their own are increasingly seen as not sustainable; more holistic views of flooding recognise the role of land as both part of the conflict and also part of the solution. This is demonstrated through the development of new policies such as the Netherlands' "Room for the River" project (Ruimte voor de Rivier) and "Making Space for Water" in the UK (Defra, 2005). These policies increasingly choose to accept flooding as a natural phenomenon to be accommodated rather than prevented. They recognise the demand that water places on land in terms of a requirement for flood storage, advocating the allocation of land specifically for flood risk mitigation measures (by reinstating floodplains) (Defra, 2005).

Yet land available for such measures is limited and under pressure from competing demands from what we might term "people uses" such as for housing or other economic activities. This raises questions about how space can be made for water, but also for people (Mitchell, 2003; Simeonova and van der Valk, 2009); it is clear that a balance must be struck between these competing demands (Borrows, 2006; Gallent, 2008). Such a balance will inevitably prioritise one element over others to a degree, but not everywhere and all of the time. Other elements could be said to "lose" and that will bring its own consequences that need to be recognized when decisions are made. How and by whom these decisions are made is a reflection of the governance arrangements that prevail at the time and the degree of learning that has been achieved from decisions made in the past.

Published by Copernicus Publications on behalf of the European Geosciences Union. 
Negotiation is a key dimension here and we can learn from a consideration of negotiation theory. Most theorising here shares the notion of negotiation as a process, but there are different interpretations. Therefore, "Structural Analysis" sees the process as a power play (Dawson, 1999), where the symmetry or asymmetry between the protagonists largely determines the outcome, although a limitation here is that this is not always the case. "Strategic Analysis" starts by assuming that both parties to a negotiation have a veto, but can cooperate or defect, and builds matrices of different responses to proposals and counter-proposals to look for "winwin" or comparable situations (Ury et al., 1991). "Process Analysis" sees the two or more parties setting out their positions and seeking to converge through a series of concessions, whilst "Integrative Analysis" divides negotiation into different stages, and the outcome as being related to the performance of the actors at each stage, akin to a hurdle race (Thompson, 2005). These theories will assist the interpretation of our results in the concluding section (4.6) of this paper.

The issue of floodplain use is a global one. This paper, however, will focus on the UK where recent regulatory change in the form of central government guidance provides a standard for what is happening on the ground. It will examine the balance that has been struck between land and water, water and people and will consider the changes to effectiveness at achieving flood risk management goals through a process of negotiation. Some lessons that may be useful for other countries are included in our conclusions.

\section{Governance and the regulatory framework}

\subsection{Spatial planning and flood risk management}

Over time has come the recognition that spatial planning (previously land use planning) needs to restrict the development of areas that experience flooding or generate flood runoff, as a non-structural alternative to continuing to have to increase the protection of developed floodplains with structural engineering works (Defra, 2005; Reiner Böhm et al., 2004).

In this respect, the Town and Country Planning Act 1947 established a mechanism for directing all development based on a largely locally determined balance between social, economic and environmental considerations (White and Richards, 2007; Wynn, 2005; Tewdwr-Jones, 2004). As such, spatial planning now allows for flood risk management to recognise and address the role that our limited land surface area plays in the conflict between water and people (White and Howe, 2002; Greckos and Woodmore, 2007; CLG, 2006a).

But local agendas are inevitably, to some extent, nationally steered. Spatial planning in the UK has been driven by broad, subject specific policies (Planning Policy Statements (PPSs), formerly Planning Policy Guidance Notes (PPGs)) produced by central government at the national level, as guidelines for the consideration of nationally important issues at the local level. The guidelines are interpreted by Local Authorities in line with local circumstances to form part of Local Development Frameworks (LDF) which in turn provide a direction for individual development decisions (Barclay, 2009; White and Richards, 2007).

The final decision is normally made at local level by the Local Authority on a case-by-case basis. However, in some cases, such as when an application is controversial or may have implications beyond the local level, it may be referred to higher authority in the form of to the Secretary of State for Communities and Local Government. If s/he agrees to consider the application then the decision will be made at the national level, but this is uncommon: the Secretary of State will generally prefer that the decision remain with the Local Authority (LA). Such a devolved process encourages the decision to focus on the local circumstances, tailoring it flexibly to local priorities (White and Richards, 2007).

\subsection{The national policy: PPS 25 and PPS 3}

The twenty-five Planning Policy Statements cover a wide range of issues, from Biodiversity and Geological Conservation (PPS 9) to Flood Risk and Development (PPS 25). Flood Risk and Development (PPS 25) began life as PPG 25, in turn expanding on advice in Circular 30/92 (DoE, 1992), in the wake of the catalytic floods in 1998 and Autumn 2000, which boosted the prominence of flooding as an issue of national importance (Johnson et al., 2007, 2004; White and Howe, 2002). Public concerns that flood risk was being exacerbated by new development (DETR, 2001) was addressed by stating its aim as "to reduce and certainly not to increase the flood risk" (DETR, 2002, p. 2). To enforce this, flooding is treated as a "material consideration" in spatial planning.

In effect PPS 25 adopts a risk based approach to protect critical space for water, encouraging development to locate out of flood risk areas (CLG, 2006a). The main instrument for achieving this is the sequential test (Fig. 1) "to ensure that further development normally avoids the areas of highest risk and that appropriate measures are taken to make development safe where other considerations .... may outweigh the flooding issues" (CLG, 2006a, p. 2). The test highlights how flood zones and their flood probabilities are to be considered to prevent the exacerbation of flood risk.

However, PPS25 does not exist in isolation and conflicts will clearly occur (Simeonova and van der Valk, 2009). PPS3 on "Housing" highlights the "making space for people" agenda by promoting a "step-change in housing delivery" (CLG, 2006b, p. 5) by local authorities, with a target approach to house building (CLG, 2006b, p. 5), unlike

\footnotetext{
${ }^{1}$ A material consideration is an aspect that may be cause for a planning application to be refused.
} 


\begin{tabular}{|c|c|c|}
\hline Definition & Appropriate uses & Policy Aims \\
\hline $\begin{array}{l}\text { Zone } 1 \text { (Low Probability): } \\
\text { Land assessed as having a } \\
\text { less than } 1 \text { in } 1000 \text { annual } \\
\text { probability of river or sea } \\
\text { flooding in any year } \\
(<0.1 \%) \text {. }\end{array}$ & $\begin{array}{l}\text { All uses of land are appropriate in this } \\
\text { zone. }\end{array}$ & $\begin{array}{l}\text { In this zone, developers and local authorities } \\
\text { should seek opportunities to reduce the overall } \\
\text { level of lfood risk in the area and beyond } \\
\text { through the layout and form of the } \\
\text { development, and the appropriate application of } \\
\text { sustainable drainage techniques. }\end{array}$ \\
\hline $\begin{array}{l}\text { Zone } 2 \text { (Medium } \\
\text { Probability): } \\
\text { Land assessed as having } \\
\text { between } 1 \text { in } 100 \text { and } 1 \text { in } \\
1000 \text { annual probability of } \\
\text { river flooding }(1 \%-0.1 \%) \text { or } \\
\text { between a } 1 \text { in } 200 \text { and } 1 \text { in } \\
1000 \text { annual probability of } \\
\text { sea flooding }(0.5 \%-0.1 \%) \\
\text { in any year. }\end{array}$ & $\begin{array}{l}\text { The water-compatible, less vulnerable } \\
\text { and more vulnerable uses of land and } \\
\text { essential infrastructure in Table D. } 2 \text { are } \\
\text { appropriate in this zone. Subject to the } \\
\text { Sequential Test being applied, the highly } \\
\text { vulnerable uses in Table d.2 are only } \\
\text { appropriate in this zone if the Exception } \\
\text { Test is passed. }\end{array}$ & $\begin{array}{l}\text { In this zone, developers and local authorities } \\
\text { should seek opportunities to reduce the overall } \\
\text { level of flood risk in the area through the layout } \\
\text { and form of the development, and the } \\
\text { appropriate application of sustainable drainage } \\
\text { techniques. }\end{array}$ \\
\hline $\begin{array}{l}\text { Zone 3a } \\
\text { Probability): } \\
\text { Land assessed as having a } 1 \\
\text { in } 100 \text { year or greater annual } \\
\text { probability of river flooding } \\
(>1 \%) \text { or a } 1 \text { in } 200 \text { or } \\
\text { greater annual probability of } \\
\text { flooding from the sea } \\
(>0.5 \%) \text { in any year. }\end{array}$ & $\begin{array}{l}\text { The water-compatible and less } \\
\text { vulnerable uses of land in Table D. } 2 \text { are } \\
\text { appropriate in this zone. The highly } \\
\text { vulnerable uses in Table D. } 2 \text { should not } \\
\text { be permitted in this zone. The more } \\
\text { vulnerable and essential infrastructure } \\
\text { uses in Table D. } 2 \text { should only be } \\
\text { permitted in this zone if the Exception } \\
\text { Test (see para. D.9) is passed. Essential } \\
\text { infrastructure permitted in this zone } \\
\text { should be designed and constructed to } \\
\text { remain operational and safe for users in } \\
\text { times of flood. }\end{array}$ & $\begin{array}{l}\text { In this zone, developers and local authorities } \\
\text { should seek opportunities to: } \\
\text { Reduce the overall level of flood risk in the } \\
\text { area through the layout and form of the } \\
\text { development and the appropriate application of } \\
\text { sustainable drainage techniques; } \\
\text { Relocate existing development to land in zones } \\
\text { with a lower probability of floodin;g; and } \\
\text { Create space for flooding to occur by restoring } \\
\text { functional floodplain and flood flow pathways } \\
\text { and by identifying, allocating and safeguarding } \\
\text { open space for flood storage. }\end{array}$ \\
\hline $\begin{array}{l}\text { Zone 3b (The Functional } \\
\text { Floodplain): } \\
\text { Land which would flood } \\
\text { witha an annual probability } \\
\text { of } 1 \text { in } 20(5 \%) \text { or greater in } \\
\text { any year, or is designed to } \\
\text { flood in an extreme }(0.1 \%) \\
\text { flood, should provide a } \\
\text { starting point for } \\
\text { consideration and } \\
\text { discussions to identify the } \\
\text { functional floodplain. }\end{array}$ & $\begin{array}{l}\text { Only the water-compatible uses and the } \\
\text { essential infrastructure listed in Table } \\
\text { D. } 2 \text { that has to be there should be } \\
\text { permitted in this zone. It should be } \\
\text { designed and constructed to: } \\
\text { Remain operational and safe for users in } \\
\text { times of flood; } \\
\text { Result in no net loss of floodplain } \\
\text { storage; } \\
\text { Not impede water flows; and } \\
\text { Not increase flood risk elsewhere } \\
\text { Essential infrastructure in this zone } \\
\text { should pass the Exception Test. }\end{array}$ & $\begin{array}{l}\text { In this zone, developers and local authorities } \\
\text { should seek opportunities to: } \\
\text { Reduce the overall level of flood risk in the } \\
\text { area through the layout and form of the } \\
\text { development and the appropriate application of } \\
\text { sustainable drainage techniques; and } \\
\text { Relocate existing development to land with a } \\
\text { lower probability of flooding }\end{array}$ \\
\hline
\end{tabular}

Fig. 1. The Sequential Test (from PPS 25, Table D1).

the PPS25 approach. Not only does PPS 3 promote development, but it also preferences the development of brownfield $^{2}$ sites, many of which - for industry - were traditionally located along sources of water transport where a flood risk is likely (DETR, 2002, p. 21). The clear contrast between the goals of the two policies led to concerns during the consultation phases as to how planners could reconcile the two aims of making space for water and making space for people (Cameron Blackhall, 2006). During the revision of the PPGs Government responded to concerns with a so-called "strengthened Planning Policy Statement" (CLG, 2006a, p. 54) which saw the addition of the exception test (Fig. 2) to PPS 25 and the promotion of the Environment Agency (the Agency) as a Statutory Consultee ${ }^{3}$. The Agency must now be notified of developments considered at risk

${ }^{2}$ A brownfield site is an area of land that has been previously developed.

${ }^{3}$ Statutory Consultees are stakeholders that must be notified and from flooding, allowing them to confirm or advise against the suitability of the proposed development.

The exception test (Fig. 2) in PPS 25 states that certain atrisk developments may be approved if certain conditions apply. These are, in summary, that "the development provides wider sustainability benefits to the community that outweigh flood risk", that the "development should be on developable previously-developed land or ... that there are no reasonable alternative sites on developable previously-developed land", and also that the "development will be safe" (CLG, 2006a, p. 27). In this way the exception test implies that meeting the conditions of developing on brownfield land and providing wider sustainable benefits (such as affordable housing) would provide benefits that outweigh flood risk.

This element of the guidance perhaps emphasizes the need to make space for people by implying that the goals of PPS 3

invited to comment on a proposal. 


\begin{tabular}{|l|l|l|l|l|l|}
\hline $\begin{array}{l}\text { Flood Risk } \\
\text { Vulnerability } \\
\text { classification } \\
\text { (see Table } \\
\text { D2) }\end{array}$ & $\begin{array}{l}\text { Essential } \\
\text { Infrastructure }\end{array}$ & $\begin{array}{l}\text { Water } \\
\text { compatible }\end{array}$ & $\begin{array}{l}\text { Highly } \\
\text { Vulnerable }\end{array}$ & $\begin{array}{l}\text { More } \\
\text { Vulnerable }\end{array}$ & $\begin{array}{l}\text { Less } \\
\text { Vulnerable }\end{array}$ \\
\hline Zone 1 & & & & & \\
\hline Zone 2 & & & $\begin{array}{l}\text { Exception } \\
\text { Test required }\end{array}$ & & \\
\hline Zone 3a & $\begin{array}{l}\text { Exception } \\
\text { Test required }\end{array}$ & & $\mathrm{X}$ & $\begin{array}{l}\text { Exception } \\
\text { Test required }\end{array}$ & \\
\hline $\begin{array}{l}\text { Zone 3b } \\
\text { 'Functional } \\
\text { Floodplain' }\end{array}$ & $\begin{array}{l}\text { Exception } \\
\text { Test required }\end{array}$ & & $\mathrm{X}$ & $\mathrm{X}$ & $\mathrm{X}$ \\
\hline
\end{tabular}

\section{Exception Test \\ a) It must be demonstrated that the development provides wider sustainability benefits to the community that outweigh flood risk, informed by a SFRA where one has been prepared. If the DPD has reached the 'submission' stage - see Figure 4 of PPS12: Local Development Frameworks - the benefits of the development should contribute to the Core Strategy's Sustainability Appraisal; \\ b) The development should be on developable previously-developed land or, if it is not on previously developed land, that there are no reasonable alternative sites on developable previously-developed land; and \\ c) A FRA must demonstrate that the development will be safe, without increasing flood risk elsewhere, and, where possible, will reduce flood risk overall.}

\footnotetext{
Key:

Development is appropriate
$\mathrm{X}$ Development should not be permitted
}

Fig. 2. The Exception Test (from PPS 25).

- which match these conditions - are more highly valued than those of PPS 25. However, PPS 25 states that "nothing in PPG 25 should be taken as departing from this [PPS 3] guidance (DETR, 2001, p. 14)". This confirms that, at the national level at least, there should be no preference for making space for people vis-à-vis making space for water. As such it is left to the spatial planners at local level to bear the burden of reconciling these policy goals where they conflict, based on their assessment of the local circumstances (Hoggett and Hambleton, 1990; Thornley as cited in Barlow, 1995).

\section{Approach and methodology}

This paper examines high level decisions about land and water by analysing five case studies, selected to show how floodplain use has been prioritised in practice at both the local and at the national level. Given that the reconciliation between competing land use aims takes place at the local level, exploring these case studies will give an insight into how the balance between land and water, water and people is achieved in practice. Each case study was chosen because flooding was a material consideration which conflicted with other planning policies such as PPS 3. As such, we are concerned with both outcomes and the decision process, and these are intertwined: as Green (2003) has noted there can be conflicts between the determination of the best outcome and the best decision process.

The case studies were selected from lists of planning applications that went to appeal and each was analysed using publicly available and extensive documentary sources. The lists were taken from the appendices of the High Level Target 5 and 12 reports (from February 2001 to August 2007) (Environment Agency, 2003, 2004, 2006a, b, 2007a, 2009). We chose the examples that had been called-in by the Secretary of State as these could be assumed to be particularly difficult cases where achieving a balance was especially challenging and which would, therefore, highlight how such conflicts have been resolved. 
Our choice was restricted to those appeals where PPS 25 issues were given as a "Reason for Agency Objection" and was informed (from the relevant Local Authority website) by the extent to which the appeal was based on PPS 25 considerations: at this point, four case studies met our criteria. The fifth case, Heybridge, was not called-in, but was analysed as it embodies a process of lengthy negotiation, providing particular insights into the difficulties of balancing the conflicts inherent in flood risk management and spatial planning.

Our aims need to be clear. When these cases were referred to the national level for the Secretary of State to make the decision and, thus, the choices, we believe this represents in essence a lack of acceptance of any compromise at the local level; the Secretary of State effectively has to make a decision that one national policy can be prioritised in these local circumstances to achieve what $\mathrm{s} / \mathrm{he}$ deems a sensible balance. We believe this is revealing, but our examples are the extremes and in no way are considered here as typical situations. Nor do we wish to make an argument that they necessarily represent policy failures for PPS 25 guidance: PPS 25 is advisory (admittedly strongly so), and not to be used totally mechanistically. The cases do, however, represent situations where the values of central government are demonstrated, which otherwise might well remain hidden, and this was a key aim of our research.

\section{Choice in practice: five case studies}

\subsection{Egham Hythe}

This case exemplifies the difficult choices and conflicts between the goals of Making Space for Water versus the targets for housing development. The developer proposed upgrading defective housing stock by demolishing the existing substandard properties and replacing them with more suitable dwellings. However, to ensure the development proved costeffective, the number of properties would be increased from 108 to 173 (Runnymede Borough Council, 2004).

The proposed development would satisfy the PPS3 target related to increasing the provision of affordable housing and would achieve this on "brownfield" land. However, the development contradicted guidance given in PPS 25 in that the location is in a flood risk area (Zone 3) (Tunstall et al., 2009) and would increase the number of dwellings exposed to the risk (Nowak, 2006). This contravenes the aim of PPS 25, which seeks to reduce the exacerbation of flood risk caused by more people living in flood risk areas (CLG, 2006a).

The Environment Agency objected on several grounds. The risk from the undefended Thames was too great, there would be no dry escape route and that the sequential test (Fig. 1) had not been carried out (Nowak, 2006). In response, the developer attempted to adapt the design by raising floor levels and incorporating void spaces beneath the properties to accommodate flood waters (Apex Housing Group, 2005).
However, the Agency maintained their objection, arguing that this measure would not sufficiently address the threat from flooding. The Agency particularly highlighted that the lack of a dry escape route remained an outstanding concern (Nowak, 2006).

Runnymede Borough Council refused planning permission for the development. In response to this decision the proposers appealed, resulting in an invitation to the Secretary of State to consider the application. In this case, the invitation was accepted and, upon consideration, the Secretary of State permitted the development, with conditions (Nowak, 2006).

The Secretary of State's decision was based on the argument that, overall, the benefits of development (under the objectives of PPS 3) outweighed the flood risk concerns (under the objectives of PPS 25). The development provided a unique opportunity to provide social benefits and that, without the development, there would remain a significant number of people living both at risk and in defective properties (Nowak, 2006).

Although the Secretary of State agreed that the sequential test had not been appropriately performed, he deemed Egham Hythe an "exceptional case" (Nowak, 2006, p. 4), thus, considering the application despite this fault, as the sequential test would cause unnecessary delays to a case which would be largely unaffected. He also agreed that the development would place more people at risk from flooding, but that the new developments would somewhat (although not completely) address the threat by raising floor levels (Nowak, 2006).

Although PPS 25 failed to "direct development away from areas of high risk" (CLG, 2006a, p. 2), there is here a degree of success for PPS 25, which was used by the Agency to promote a process of negotiation which prompted the developer to re-design the buildings to mitigate the flood risk. Thereby PPS 25, the planning process and planners, were also flexible enough to allow the Secretary of State to recognise the social benefits of the development and to weigh these against flood risk, rather than be confined by a more rigid policy.

\subsection{Maidenhead}

The Maidenhead proposal is similar to Egham Hythe in also comprising the redevelopment of brownfield land, but in this case to allow the building of 74 "key worker" and "affordable" flats (apartments). The application of PPS 25 demonstrated that the development was at significant risk from flooding, being located in Zones 2 and 3a (Fig. 1) (Royal Borough of Windsor and Maidenhead, 2006). As the sequential test in PPS 25 demonstrates, the development proposed is considered "More Vulnerable" than the pre-existing use of that floodplain land, requiring the satisfaction of the exception test (Fig. 3) (Wildsmith, 2008). But as the test is based upon the need to satisfy housing criteria, this development 
would pass that test, as the properties were to be "affordable" and would also develop brownfield land.

When consulted, the Environment Agency initially objected to the proposal, stating that the sequential and exception tests had not been applied correctly, as it had not been demonstrated that no alternative site was available. Safety was also a key issue. The Agency was particularly concerned that there would be no "safe" access to the site in the event of a flood, deeming the site "not safe" overall. The safety of the development was also considered to rely on Agencyissued flood warnings, which could not be guaranteed to be received by all those at risk (Wildsmith, 2008).

In order to mitigate the Agency's objections, the developer here also modified the plans by raising the floor levels and providing void spaces beneath the floors to prevent the displacement of floodwaters by the development, increasing risk elsewhere on the floodplain (Wildsmith, 2008). The modifications introduced were accepted as "reducing" the level of flood risk, and demonstrate the effect of the negotiation process and the consideration of PPS 25 guidance (Woodhouse, 2009). When considered by the Secretary of State, it was deemed that, whilst not a removal of risk entirely, a reduction was adequate and sufficient enough for the development to be permitted (Wildsmith, 2008).

The Maidenhead case highlights that PPS 25 was effective in requiring efforts to mitigate such risks through the negotiation process between the Agency as statutory consultee and the developer. However, the policy, again, failed to prevent an increase in the number of people living at risk of flooding (Wildsmith, 2008). This directly contradicts part of PPS 25's objectives (CLG, 2006a). Moreover, in permitting the development, the Secretary of State agreed to allow low income and, hence, vulnerable families to increase their occupance of the floodplain, whereas if the housing had not been "affordable", and occupied by higher income groups, the development would likely not have been permitted. Also, a stricter application of the PPS 25 rules could have resulted in no development being permitted at all, whilst the "balanced, flexible approach" promoted by PPS 25 resulted in the development proceeding, but with reduced risk, emphasizing the value of the negotiation and mediation processes (Wildsmith, 2008).

\subsection{City of York}

The previous two cases demonstrate how negotiation processes encouraged mitigation measures that address the flood risk so that development may proceed. Whilst these measures are a useful tool in facilitating a resolution of the conflict between development targets and flood risk, the approach implies a reliance on physical solutions, counteracting national level attempts towards safeguarding natural floodplains (Defra, 2005).

The case of York (City of York Council, 2003) demonstrates these flaws and repeats the somewhat strange preference towards affordable housing developments to overcome certain flood risk concerns. The development was submitted in 2003 as an outline planning application for a comprehensive scheme to build 540 dwellings (City of York Council, 2003), thereby exceeding local targets for affordable housing (City of York Council, 2006), but on land comprising a mixture of flood zones 1, 2 and 3 (Cullingford, 2007). At the time, PPS 25 was available in draft form only. Given that the development was of such a significant size, it was decided that the application should be considered under the draft in order to ensure its compliance with the most up-to-date guidance available (Cullingford, 2007).

Flood risk mapping was a key issue here. The Agency flood maps were first available after the developer had arranged their own modelling and mapping. This caused confusion and conflict as the different maps did not agree on the level of flood risk. The Agency maps showed the site with some areas categorised as low risk in zone 1, but other parts categorised as high risk zone 3 . The developer's maps highlighted watercourses as being vulnerable to blockages, but was criticised as the models could not show flood velocities, which was considered misleading (Osbaldwick Parish Council et al., 2005).

Based on their maps, the Agency objected to the proposed development, citing flood risk concerns, and they were supported by public objections highlighting the site's proneness to water logging and surface water flooding. In response, the developer attempted to address the risk by developing mitigation measures such as a bund. This was criticised as inappropriate given that the site was underlain by clay soils prone to groundwater flooding, a bund being more suitable for flooding from fluvial sources (Cullingford, 2007).

The developer appealed against the decision to reject permission and the case was then referred to the Secretary of State who agreed to call in the application. At the call-in stage, the Secretary of State commented that "there is an urgent need to grant planning permission for the proposal now to meet the housing requirements for York" (Cullingford, 2007, p. 30) and that the development "would represent a very significant contribution to meeting the need for affordable housing in York" (Cullingford, 2007, p. 258). The attraction of such a large proportion of affordable housing as an opportunity to meet PPS 3 targets was a key factor in promoting the decision to permit the development.

In the Secretary of State's report, a comment was made that the Environment Agency "has withdrawn its objection to the application" (Cullingford, 2007, p. 188), downplaying its initial concerns. Furthermore, the Secretary of State argued that any flood risk could be overcome by the implementation of physical solutions. Whilst such solutions may indeed reduce the risk, they cannot prevent all possible flood events and may even exacerbate risk elsewhere (House of Commons, 2000). The final outcome was for permission to be granted with conditions to mitigate the level of flood risk. 


\begin{tabular}{|c|c|}
\hline $\begin{array}{l}\text { Essential } \\
\text { Infrastructure }\end{array}$ & $\begin{array}{l}\text { Essential transport infrastructure (including mass evacuation routes) which } \\
\text { has to cross the area at risk. } \\
\text { Essential utility infrastructure which has to be located in a flood risk area } \\
\text { for operational reasons, including electricity generating power stations and } \\
\text { grid and primary substations; and water treatment works that need to remain } \\
\text { operational in times of flood. } \\
\text { Wind turbines. }\end{array}$ \\
\hline & $\begin{array}{l}\text { Police stations, Ambulance stations and Fire stations and Command centres } \\
\text { and telecommunications installations required to be operational during } \\
\text { flooding } \\
\text { Emergency dispersal points } \\
\text { Basement dwellings } \\
\text { Caravans, mobile homes and park homes intended for permanent residential } \\
\text { use } \\
\text { Installations requiring hazardous substances consent. (Where there is a } \\
\text { demonstrable need to locate such installations for bulk storage of materials } \\
\text { with port or other similar facilities, or such installations with energy } \\
\text { infrastructure or carbon capture and storage installations, that require coastal } \\
\text { or water-side locations, or need to be located in other high flood risk areas, } \\
\text { in these instances the facilities should be classified as 'Essential } \\
\text { Infrastructure'). }\end{array}$ \\
\hline $\begin{array}{l}\text { More } \\
\text { Vulnerable }\end{array}$ & $\begin{array}{l}\text { Hospitals. } \\
\text { Residential institutions such as residential care homes, children's home, } \\
\text { social services homes, prisons and hostels. } \\
\text { Building used for: dwelling houses; student halls of residence; drinking } \\
\text { establishments; nightclubs; and hotels. } \\
\text { Non-residential uses for health services, nurseries and educational } \\
\text { establishments. } \\
\text { Landfill and sites used for waste management facilities for hazardous waste. } \\
\text { Sites used for holiday or short-let caravans and camping, subject to a } \\
\text { specific warning and evacuation plan. }\end{array}$ \\
\hline
\end{tabular}

Fig. 3. The sequential test classification of development types (from PPS 25, Table D2).

Despite the development potentially exposing considerable numbers of dwellings and, therefore, people to flood risk, the appeal of satisfying the PPS 3 targets was much greater than flood risk concerns. This highlights the weakness in PPS 25 vis-a-vis PPS 3, with the latter taking priority over sustainability objectives promoted by PPS 25 .

\subsection{Windsor}

This case consists of a proposed development which would place particularly vulnerable individuals at risk. The plan was for the development of an 80-bed old peoples' care home, as four blocks of 53 flats, to replace a disused factory (Carter Planning Limited, 2006). The derelict site was known to attract criminal activity such as vandalism and this particularly concerned its neighbours. As such, public consultation responses from local people were generally positive, welcoming the proposed development as an opportunity to improve the quality of their surroundings (Smith, 2006; Skinner, 2006).
However, the site is at risk from flooding and, according to the Agency's maps, is located in an area of significant risk (zone 3a; Fig. 1) (Peter Brett Associates, 2006a). Considering the nature of the development (categorised as "More Vulnerable" - see Fig. 3) (Peter Brett Associates, 2006b), the Agency would require the satisfaction of the exception test. The Agency, therefore, argued in favour of refusing planning permission, highlighting the issue of out-of-date flood maps used by the developer, the increased number of people to be placed at risk from flooding, and that the escape route would not be dry during a flood (Watson, 2008; Share, 2006; Rose, 2006).

In such cases, the precise meanings of words in rules and guidance becomes important. Arguments focused on whether the requirement of PPS 25 for a "safe" access route implied a "dry" (i.e., flood-free) route. The developer argued that whilst the escape route might not be "dry", it would be "safe" as the depth and velocities would be low enough to allow its use during a flood. Flood waters would be very slow moving and at a maximum depth of $400 \mathrm{~mm}$ (Hillyer, 
Table 1. "To Do" list set by Environment Agency consultation reply of October 2006.

\begin{tabular}{|c|c|c|c|}
\hline Issue & Action required & How resolved & By when \\
\hline \multirow[t]{2}{*}{$\begin{array}{l}\text { 2: Sequential test- no evidence } \\
\text { of application }\end{array}$} & \multirow[t]{2}{*}{ Demonstrate sequential test application } & $\begin{array}{l}\text { Council felt sequential test had been } \\
\text { conducted but EA required site specific } \\
\text { sequential test }\end{array}$ & January 2007 \\
\hline & & $\begin{array}{l}\text { Sequential test demonstrated and } \\
\text { accepted }\end{array}$ & April 2007 \\
\hline $\begin{array}{l}\text { 3: FRA relates to a differ- } \\
\text { ent/altered/previous proposal }\end{array}$ & FRA to accurately reflect proposal & Updated FRA produced & December 2006 \\
\hline $\begin{array}{l}\text { 4: Raised flood levels not deter- } \\
\text { mined properly and model too } \\
\text { simplistic }\end{array}$ & $\begin{array}{l}\text { Carry out } 2-\mathrm{D} \text { modelling to look at } \\
\text { overtopping and breach scenarios }\end{array}$ & 2-D breach analysis submitted & August 2007 \\
\hline \multirow[t]{2}{*}{ 5: Safety of development } & \multirow[t]{2}{*}{$\begin{array}{l}\text { Ask emergency services and emergency } \\
\text { planners if it would be safe }\end{array}$} & Proposed access route accepted & March 2007 \\
\hline & & Raised walkway suggested & August 2007 \\
\hline $\begin{array}{l}\text { 6: Accommodating additional } \\
\text { volumes of surface water from } \\
\text { development not demonstrated }\end{array}$ & $\begin{array}{l}\text { More detailed evaluation of the abil- } \\
\text { ity of existing surface water systems to } \\
\text { cope with the additional volumes of wa- } \\
\text { ter arising from the site and details of } \\
\text { site control measures to cope with the } \\
\text { additional run-off from the site before } \\
\text { the determination of the application }\end{array}$ & $\begin{array}{l}\text { Run-off rates demonstrated but calcula- } \\
\text { tion of these needed to be demonstrated }\end{array}$ & January 2007 \\
\hline
\end{tabular}

2008), thus, satisfying a technically correct interpretation of "safety" in PPS 25.

However, this assessment appears to take little account of the particular vulnerability of the escape route users. The residents of the care home would almost certainly have mobility problems and would, therefore, require considerable time and support to be evacuated on foot, whilst probably suffering considerable stress, even if safe evacuation were possible at all. Nevertheless, the Secretary of State ultimately granted permission for the development with conditions (Watson, 2008).

The decision recorded that the sequential test had been conducted correctly. The scheme would reduce overall floods depths at the site. Floor levels would be set above the 1 in $100 \mathrm{yr}$ flood level and there would be elements of resilient construction (Watson, 2008). The conclusion was that "whilst the development would introduce a greater number of people into a high probability flood zone, and for longer periods of time, the Secretary of State was satisfied that the development would be flood resilient and resistant, would include safe access and escape routes, and its residual risk could be safely managed" (Watson, 2008, p. 5).

Opportunities here to make a wider social and economic contribution through improving the quality of neighbourhoods appear to have outweighed the concerns over safety that are posed by flood risk. The beneficiaries of the decision were the wider community, whereas those living on the site will be considerably more vulnerable when flooding occurs than had the development occurred elsewhere.

\subsection{Heybridge}

The Heybridge case study demonstrates how negotiation can be used incrementally to achieve a compromise accepted by all, and our research here was assisted by the availability of many letters between the Agency, developer and planners 
discussing the issues and objections (Maldon District Council, n.d.).

The proposed development envisaged the construction of 14 dwellings on brownfield land in the form of a disused petrol station (Maldon District Council, n.d.). However, the development was to be located in flood zone $3 \mathrm{a}$ (Fig. 1) and, hence, exposed to a significant level of flood risk (AERC, 2006). This led the Agency to object to the development, arguing that it would increase the risk of flooding to preexisting developments, where residents would be forced to accept that new risk. Also the developer had not applied the sequential test and had provided an inadequate Flood Risk Assessment (AERC, 2006; Environment Agency, 2006c). The Agency concluded that the development would not, therefore, be safe (Environment Agency, 2006c). However, by listing the reasons for the objection, the Agency provided, in effect, an agenda or "to do" list for the developer to overcome the objection by improving the standard of the development (see Table 1).

The developer and Agency underwent a prolonged period of negotiation (10 months) (e.g., Essex County Council, 2006; Environment Agency, 2007b) where the developer tackled the various aspects of the Agency's objections one by one until the Agency agreed that its objections had been satisfied. This negotiation resulted in re-submissions of the Flood Risk Assessment to the satisfaction of the Agency, and a demonstration of the application of the sequential test (e.g., Environment Agency, 2006c; Emptage Architects, 2006). When these objections had been satisfied the planning authority deemed the development suitable for the location and permitted it (Maldon District Council b, n.d.), with certain conditions for flood risk protection (e.g., all sleeping accommodation to be above the ground floor (Maldon District Council b, n.d.). The Agency retained its objection for other reasons, besides the flood risk, related to contaminated land matters, but these were not considered by the Local Planning Authority to be sufficient to prevent the development (Maldon District Council b, n.d.). This suggests that PPS 25 was successful in elevating the consideration of flood risk and strengthening the Agency's case in the planning process where other issues do not carry the same weight because the Agency is only a statutory consultee on flooding issues.

The Heybridge case again demonstrates that the presence of PPS 25 promotes the negotiated consideration and mitigation of flood risk in developments. The example emphasizes that the complex and necessarily lengthy negotiation process is the key to achieving compromises and making the choices necessary to address the inherent conflicts of PPS 3 and PPS 25. However, like all the others, this case demonstrates that flood risk alone is not sufficient to prevent a development. The targets of PPS 3 to provide affordable housing and its encouragement of developments on brownfield land, promote the achievement of these annual short-term targets at the expense of the longer term goals of reducing flood risk.

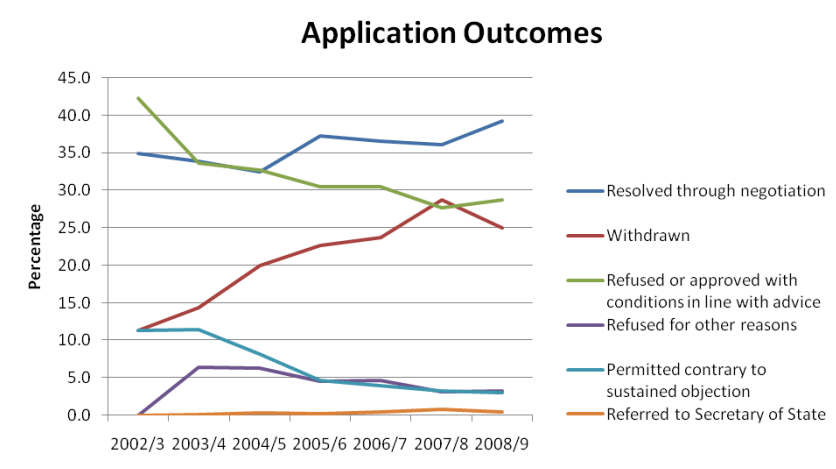

Fig. 4. The outcomes of applications (from Environment Agency High Level Targets 5 and 12).

\subsection{What can we learn about floodplain policies and processes?}

The case studies above highlight that, in practice, PPS 25 is not strong enough to support the refusal of a development where other important issues are raised and targets conflict. But these case studies should be put in context. The PPS 25 arrangements appear to have had a profound effect in restraining floodplain development (Fig. 4). Let us consider how our case studies fit into this overall picture.

The outcomes of the case studies suggest that the balance in practice favours making space for people rather than making space for water. However, this is an oversimplification: flood risk is clearly mitigated through the spatial planning process, with extra consideration and additional measures and modifications being made to reduce the level of risk to the development. With the flexible approach of local decision making it transpires that where the benefits are judged to outweigh the risks, development may proceed with riskreducing adaptive measures that might otherwise have been neglected.

These compromises are the result of the negotiation that ensues where conflicts exist between PPS 25 and PPS 3. The new role of the Environment Agency as Statutory Consultee forces the need for this negotiation process: the Agency's advice and perspective must be taken into account in the decision making process. In practice, the case studies (in particular Heybridge) demonstrate that spatial planners even see a need now not just to consider but to satisfy the Environment Agency where its objections are reasonable. But in the case studies above, it is also clear that the short term goals of meeting annual housing targets (and, thus, making space for people) triumph over the longer term objectives of flood risk reduction. However, the Agency objections (based on PPS 25 instructions and supported by its more powerful role than hitherto), in effect, provide a "to do" list (Table 1) for developers hoping to win planning approval. This results in safer developments, better designed to withstand flood risk. Moreover, as the Heybridge case highlights, where the Agency did 
Table 2. Summary interpretations of the negotiation process.

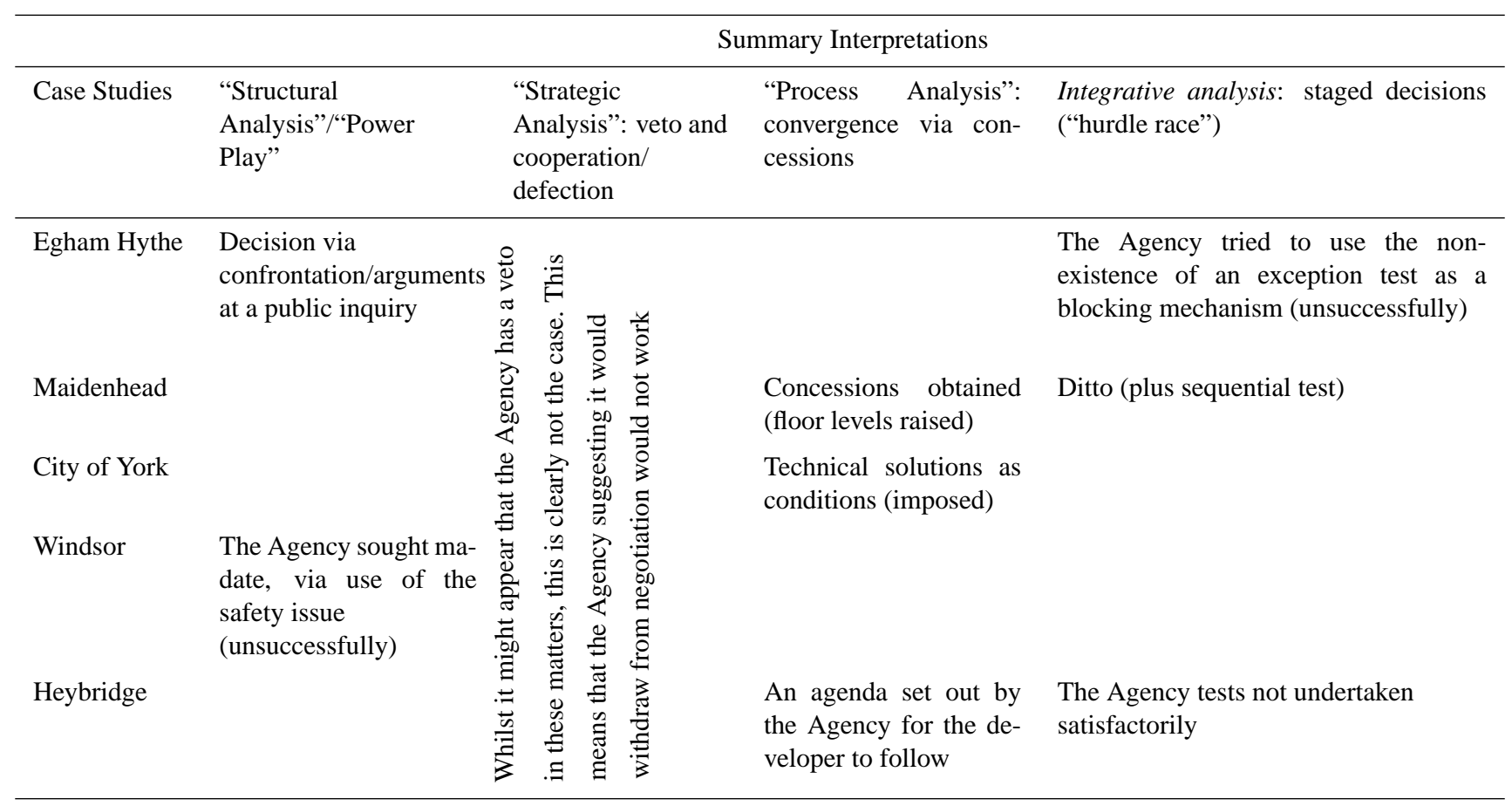

not have that status (even on the same project), its objections appeared to carry less weight. We learn, therefore, that while the PPS policy may not be perfect, it is a significant step forward.

What we can see from our case studies is that several elements of the various interpretations and theorising of negotiation discussed earlier are relevant and useful (Table 2). The new power of the Agency as a Statutory Consultee has corrected a previous asymmetry, whereby it was often a loser in the "Power Play" with influential and tenacious local authorities and/or developers. But the best fit appears to be with the notion of negotiation as a staged process, with convergence achieved by the Agency setting out an agenda or route-map for the developer, such that each hurdle jumped leads to the next task until negotiations are deemed completed. In our cases, this process of setting out the route map was still not sufficient: un-reconcilable issues had to be settled by the superior power of the Secretary of State. However, in many other cases where floodplain development has been disputed, the negotiation was clearly successful in so far as agreement was achieved (for good or ill).

The implication is that in each case of disputed floodplain development, the process of reaching an agreement needs to learn from this negotiation theory. It needs to recognise $a b$ initio who has power to over-ride the objections of others, make the staged process simpler and clearer to all involved, and to ensure that proposed concessions can be mutually agreed upon. All parties need to ensure that that convergence is maximised so that the decision is not taken out of their hands and made by the Secretary of State, which, surely, is not generally the best way forward for wise flood risk management.

\section{Conclusions}

In a crowded country the conflict between land and water, water and people centres on the need to strike a balance between competing demands on limited land space. The aim of this paper has been to examine how such conflict is resolved in the UK through the spatial planning process, where land for water is represented by PPS 25 and land for people is represented by PPS 3 . We have examined which aspect of the conflict is favoured when the two societal goals collide.

Our principal conclusion is that the UK system appears flexible and centred on a case-by-case approach - a strong and enduring characteristic of the British spatial planning system. The post-PPS 25 era has seen far greater consideration of flood risk throughout the planning process (where appropriate), but this has not enforced a strict prohibition on developments in flood risk locations: these have undoubtedly been permitted.

However, as our research demonstrates, this is not necessarily a bad thing, nor does it represent a failure of PPS 25 . As the case studies particularly demonstrate, developments are permitted where "the benefits outweigh the concerns". Frequently the benefits are deemed as the achievement of 
Table 3. Examples of spatial planning policy in other European countries.

\begin{tabular}{|c|c|c|c|}
\hline Country & National Level & Regional or Local level & Notes \\
\hline Czech Republic & $\begin{array}{l}\text { Strict policy on Active } \\
\text { Zones }\end{array}$ & $\begin{array}{l}\text { Water Authority may } \\
\text { stipulate further } \\
\text { restrictions }\end{array}$ & $\begin{array}{l}\text { Active zones of flood plains designated at national level: no building } \\
\text { permitted } \\
\text { Flood plains: water authority may stipulate restrictive conditions (Par- } \\
\text { liament of the Czech Republic, 2001; Saxon State Ministry of the Inte- } \\
\text { rior, 2006). }\end{array}$ \\
\hline Austria & $\begin{array}{l}\text { Strict policy on hazard } \\
\text { zones }\end{array}$ & $\begin{array}{l}\text { Additional measures } \\
\text { can be assigned }\end{array}$ & $\begin{array}{l}\text { Hazard zones (multi-hazards, not only flooding) defined at national } \\
\text { level, federal level assigns additional measures. Strict approach to "red" } \\
\text { zones. Can result in blight (Saxon State Ministry of the Interior, 2006). }\end{array}$ \\
\hline Germany & No national framework & $\begin{array}{l}\text { Priority zones assigned } \\
\text { by regions }\end{array}$ & $\begin{array}{l}\text { Federal system, no overall management or set standard. Regions assign } \\
\text { "priority zones" to be free of "competing demands". These zones are } \\
\text { binding at the local level. There are also decrees to protect floodplains } \\
\text { but these are limited to outside existing settlements. Implementation } \\
\text { varies depending on region (Saxon State Ministry of the Interior, 2006; } \\
\text { Böhm et al., 2004; Klijn et al., 2008). }\end{array}$ \\
\hline \multirow[t]{4}{*}{ Poland } & \multirow{4}{*}{$\begin{array}{l}\text { Classifications set } \\
\text { restrictions }\end{array}$} & & Two classifications: \\
\hline & & & 1. Land at imminent risk (land between river and defence structures) \\
\hline & & & $\begin{array}{l}\text { 2. Land at potential risk (land at risk in the event of defence failure } \\
\text { or standard of protection being exceeded) }\end{array}$ \\
\hline & & & $\begin{array}{l}\text { No uniform reference event used (Saxon State Ministry of the Interior, } \\
\text { 2006). }\end{array}$ \\
\hline Hungary & Land zoning approach & & $\begin{array}{l}\text { Land zoning approach used. No new development permitted in desig- } \\
\text { nated water storage areas - strict approach (Saxon State Ministry of the } \\
\text { Interior, 2006; Klijn et al., 2008). }\end{array}$ \\
\hline Italy & $\begin{array}{l}3 \text { Bands, A and B } \\
\text { prohibit development }\end{array}$ & $\begin{array}{l}\text { Band } \mathrm{C} \text { restrictions } \\
\text { are designed and } \\
\text { implemented }\end{array}$ & $\begin{array}{l}\text { Federal style system results in varied approaches. Previously land at } \\
\text { risk was sold quickly and cheaply for development. } \\
\text { Land defined by three bands: } \\
\text { A: land at risk from } 80 \% \text { of discharge of the } 1 \text { in } 200 \mathrm{yr} \text { flood } \\
\text { B: land at risk from } 100 \% \text { of discharge of the } 1 \text { in } 200 \mathrm{yr} \text { flood } \\
\text { C: } 1 \text { in } 500 \text { yr flood } \\
\text { Bands A and B fall within the responsibility of the River Authority. } \\
\text { Within these areas building is strictly forbidden } \\
\text { Band C falls within the responsibility of the municipality. This band is } \\
\text { often sub-divided as it covers a large area and could result in blight if } \\
\text { building is completely prohibited. Implementation varies depending on } \\
\text { the region, but exceptions and ways around the legislation are possible } \\
\text { (De Wrachien et al., 2008; Klijn et al., 2008). }\end{array}$ \\
\hline Netherlands & $\begin{array}{l}\text { Specified safety } \\
\text { standards }\end{array}$ & & $\begin{array}{l}\text { Set specified safety standards. Flood prone land is only available for } \\
\text { agriculture or nature. Exceptions are possible, but no large projects } \\
\text { such as large housing developments permitted (Klijn et al., 2008). }\end{array}$ \\
\hline Switzerland & $\begin{array}{l}\text { Spatial plans set for } \\
\text { regions to identify } \\
\text { hazard zones }\end{array}$ & $\begin{array}{l}\text { Cantons may provide } \\
\text { further definition and } \\
\text { restriction }\end{array}$ & $\begin{array}{l}\text { Regional spatial plans are binding and act as a central tool to identify } \\
\text { hazard risk areas. Hazard zones may be further defined at the level } \\
\text { of the Cantons. Restrictions relating to hazard zones vary but most } \\
\text { Cantons forbid development although exceptions may be possible with } \\
\text { precautionary measures (Böhm et al., 2004). }\end{array}$ \\
\hline France & $\begin{array}{l}\text { Strict policy on } \\
\text { development in high } \\
\text { risk areas }\end{array}$ & & $\begin{array}{l}\text { Prevention plan: state level instrument which is applied at the local } \\
\text { level. } \\
\text { New developments in flood risk areas are restricted by law. Flood risk } \\
\text { zone boundaries can be contested due to the impacts of a strict prohibi- } \\
\text { tion on development (Böhm et al., 2004; Ten Brinke et al., 2008). }\end{array}$ \\
\hline Spain & $\begin{array}{l}\text { Strict approach to } \\
\text { risk areas, including } \\
\text { removal of buildings } \\
\text { that pose serious risk to } \\
\text { people }\end{array}$ & & $\begin{array}{l}\text { Building in hydrological areas is forbidden and those already in place } \\
\text { should be removed. However, evidence that implementation is not strict } \\
\text { (Tucasa, 2010; Carlos, 2001). }\end{array}$ \\
\hline
\end{tabular}


PPS 3 targets such as providing a large number of affordable housing which satisfies important wider societal needs.

Table 3 demonstrates that in other countries, negotiation is not centre-stage. In the USA, spatial planning as zoning is a mandatory element of the subsidised flood insurance programme (Burby, 2000). Austria and France also apply stricter control on spatial planning in relation to flood risk than is the case in the UK. There, development on so-called "legal floodplains" is prohibited altogether (e.g., Lebensministerium online; Pottier et al., 2005). In some cases, steps are even taken to reduce the numbers living in flood risk locations by prohibiting reconstruction of buildings destroyed by flood events (Aubrecht et al., 2009; APFM, 2007) or by requiring the removal of buildings in high risk areas as in Spain (Carlos, 2001). In this regard some commentators would contend that all urban use of floodplain areas should be actively discouraged, and that we should universally make space for water. However, it is not logical to forbid the development of floodplain areas with intensified human use when the UK Parliament and many government offices are sited usefully on the Thames tidal floodplain in London (as an example) or when $60 \%$ of all Grade 1 UK agricultural land is to be found in other protected floodplain locations. It is more logical to suggest that we should make space for flooding, but not sterilise that space in opting just for that role: PPS25, and the negotiations that it forces, help us in this direction.

The new PPS 25 policy, then, appears to be let down only by its rhetorical ambitions when, in its introductory text, its main aim is given as "to reduce and certainly not to increase the flood risk" (DETR, 2002, p. 2) Our research has demonstrated that through a sensible process of negotiation, where both sides are balanced in terms of power, the flexible approach adopted by the UK allows compromises to be made that balance the inherent conflicts of water and people on land. This is not a simple procedure, but the result is that important developments may still be permitted, and that the embedded negotiation processes in the post-PPS25 era are requiring all those involved to make these developments safer and better prepared for the flood risk that they face. Other countries may be able to learn from these new policy directions and the advantages that a flexible negotiated approach can provide.

Acknowledgements. We acknowledge the contribution of Iain White during the preliminary stages of this research.

Edited by: F. Luino

Reviewed by: A. Assmann and another anonymous referee

\section{References}

Apex Housing Group: Revised Planning Application, Application Ref: RU.04/1050, available at: http://ww2.runnymede.gov.uk/ home/latest/wklyplanapps/2005/wk19/Plan_lst.htm, last access: 12 January 2011, 2005.

Applied Environmental Research Centre (AERC): Flood Risk Assessment, Application Ref: 06/01035/FUL, available at: http://myplan80.maldon.gov.uk/Planning/lg/ GFPlanningDocuments.page, last access: 1 December 2010, 2006.

Associatated Programme on Flood Management (APFM): The Role of Land-Use Planning in Flood Management; A Tool for Integrated Flood Management, available at: http://www.apfm.info/ pdf/ifm_tools/Tools_The_Role_of_Land_Use_Planning_in_FM. pdf, last access: 20 November 2010, 2007.

Aubrecht, C., Köstl, M., Knoflacher, M., and Steinnocher, K.: The importance of active public communication - Settlement systems and land use patterns seen from a disaster perspective, in: Real Corp Proceedings/Tagungsband, Stiges, 22-25 April 2009, available at: http://www.corp.at/archive/CORP2009_140.pdf, last access: 16 September 2010, 2009.

Barclay, C.: Planning and Flooding, House of Commons Library, available at: http://www.parliament.uk/commons/lib/research/ briefings/snsc-04100.pdf, last access: 10 February 2009, 2009.

Barlow, J.: Public Participation in Urban Development: The European Experience, PSI Publishing, London, 1995.

Böhm, H., Haupter, B., Heiland, P., and Dapp, K.: Implementation of flood risk management measures into spatial plans and policies, River Res. Appl., 20, 255-267, 2004.

Borrows, P.: Living with Flooding-Noah's Legacy, Irrigation and Drainage, 55, S133-S140, 2006.

Burby, R. J.: Residential flood insurance and floodplain management: Lessons from the United States, in: Residential flood insurance; The implications for floodplain management policy, edited by: Smith, D. I. and Handmer, J., Water Research Foundation of Australia, Canberra, 11-40, 2002.

Cameron Blackhall, J.: Planning Law and Practice, 3rd Edn., Cavendish Publishing, Abingdon, 2006.

Carlos, J. (Rey de Espana): Plan Hidrológico Nacional, Ley 10/2001, Boletín Official del Estado 161, 2001.

Carter Planning Limited: Statement on Town Planning Matters, Application Forms pdf 750115, available at: http://www.rbwm.gov.uk/pam/planning_application_search. jsp?appnum=06\%2F01347\%2FFULL, last access: 13 July 2010, 2006.

City of York Council: Planning Application 03/02709/OUT, available at: http://planning.york.gov.uk/PublicAccess/ tdc/DcApplication/application_detailview.aspx?caseno= 0302709OUT, last access: 10 July 2010, 2003.

City of York Council: Planning Inquiry, report-216975 pdf, available at: http://planningdocs.york.gov.uk/WAM/showCaseFile. do? action=show $\&$ appType $=$ planning $\&$ appNumber $=03 / 02709 /$ OUT, last access: 10 July 2010, 2006.

Cullingford, D. R.: Report to the Secretary of State for Communities and Local Government; City of York Council Applications by Persimmons Homes Limited, Hogg Builders Limited and the Joseph Rowntree Housing Trust, report 292365 pdf, available at: http: //planningdocs.york.gov.uk/WAM/showCaseFile.do?action= 
show\&appType $=$ planning $\&$ appNumber $=03 / 02709 /$ OUT,$\quad$ last access: 14 December 2010, 2007.

Dawson, R.: Secrets of Power Negotiating - Inside Secrets from a Master Negotiator, Career Press, London, 1999.

Department for Communities and Local Government (CLG): Planning Policy Statement 25: Development and Flood Risk, CLG, London, 2006a.

Department for Communities and Local Government (CLG): Planning Policy Statement 3: Housing, CLG, London, 2006b.

Department of Environment (DoE): Circular 30/92, DoE, London, 1992.

Department for Environment, Food and Rural Affairs (Defra): Making Space for Water: Taking Forward a New Government Strategy for Flood and Coastal Erosion Risk Management in England; first government response to the autumn 2004 making space for water consultation exercise, available at: http://www.defra.gov. uk/Environ/Fcd/policy/strategy.htm, last access: 20 December 2009, 2005.

Department for Environment, Transport and the Regions (DETR): Planning Policy Guidance Development and Flood Risk: Revised Consultation Paper, DETR, London, 2001.

Department for Environment, Transport and the Regions (DETR): Planning Policy Guidance 25; Development and flood Risk, available at: http://www.planning-applications.co.uk/ppg25_ floodrisk.pdf, last access: 24 January 2009, 2002.

De Wrachien, D., Mambretti, S. and Sole, A.: Risk Analysis and Vulenrability Assessment in Flood Protection and River Basin Management, WIT Transactions on Ecology and the Environment, 118, WIT Press, 2008.

Emptage Architects: Ammended Plans 19/12/06, available at: http://myplan80.maldon.gov.uk/Planning/lg/ GFPlanningDocuments.page, last access: 5 January 2010, 2006.

Environment Agency: High Level Target 12; Development and Flood Risk in England 2002/03; Report to Department for Environment, Food and Rural Affairs (Defra) and the Office of the Deputy Prime Minister, Environment Agency and Local Government Association, Bristol, 2003.

Environment Agency: High Level Target 12; Development and Flood Risk in England 2003/04; Report to Department for Environment, Food and Rural Affairs (Defra) and the Office of the Deputy Prime Minister, Environment Agency and Local Government Association, Bristol, 2004.

Environment Agency: High Level Target 5; Development and Flood Risk in England 2004/05; Report to Department for Environment, Food and Rural Affairs (Defra) and the Office of the Deputy Prime Minister, Environment Agency and Local Government Association, Bristol, 2006a.

Environment Agency: High Level Target 5; Development and Flood Risk in England 2005/06; Report to Department for Environment, Food and Rural Affairs (Defra) and Communities and Local Government (CLG), Environment Agency and Local Government Association, Bristol, 2006b.

Environment Agency: Consultation Replies 25/10/06, available at: http://myplan80.maldon.gov.uk/Planning/lg/ GFPlanningDocuments.page, last access: 17 July 2010, 2006c.

Environment Agency: High Level Target 5; Development and Flood Risk in England 2007/08; Report to Department for Environ- ment, Food and Rural Affairs (Defra) and Communities and Local Government (CLG), Environment Agency, Bristol, 2007a.

Environment Agency: Consultation Replies 14/08/07, available at: http://myplan80.maldon.gov.uk/Planning/lg/ GFPlanningDocuments.page, last access: 12 September 2010, 2007b.

Environment Agency: High Level Target 5; Development and Flood Risk in England 2007/08; Report to Department for Environment, Food and Rural Affairs (Defra) and Communities and Local Government (CLG), Environment Agency, Bristol, 2009.

Essex County Council: Consultation Replies 23/10/06, available at: http://myplan80.maldon.gov.uk/Planning/lg/ GFPlanningDocuments.page, last access: 10 October 2010, 2006.

Gallent, N.: Strategic-Local Tensions and the Spatial Planning Approach in England, Planning Theory and Practice, 9(3), 307-323, 2008.

Greckos, M. and Woodmore, A.: Turning the Tide? PPS 25: Development and Flood Risks, Journal of Planning and Environment Law, 2, 835-842, 2007.

Green, C. H.: Handbook of Water Economics, John Wiley, Chichester, 2003.

Green, C. H. and Penning-Rowsell, E. C.: Inherent Conflicts at the Coast, Journal of Coastal Conservation, 5, 153-162, 1999.

Hillyer, M.: Report to the Secretary of State for Communities and Local Government, Appeal General pdf 11094091, available at: http://www.rbwm.gov.uk/pam/planning_application_search. jsp?appnum $=06 \% 2 \mathrm{~F} 01347 \% 2 \mathrm{FFULL}$, last access: 13 January 2011, 2008.

Hogget, R. and Hambleton, R.: Decentralisation and Democracy; Localism Public services, Occasional Paper 28, University of Bristol, School for Advanced Urban Studies, 1990.

House of Commons: Environment, Transport and Regional Affairs - Appendices to the Minutes of Evidence, available at: http://www.publications.parliament.uk/pa/cm200001/ cmselect/cmenvtra/64/64ap01.htm, last access 12 April 2009, 2000.

Johnson, C., Tunstall, S., and Penning-Rowsell, E.: Crises as Catalysts for Adaptation: Human Response to Major Floods, Research Report, ESRC Environment and Human Behaviour New Opportunities Programme, 2004.

Johnson, C., Penning-Rowsell, E., and Parker, D.: Natural and imposed injustices: the challenges in implementing "fair" flood risk management policy in England, Geogr. J., 173(4), 374-390, 2007.

Klijn, F., Samuels, P., and Van Os, A.: Towards Flood Risk Management in the EU: State of affairs with examples from various European countries, International Journal of River Basin Management, 6(4) 307-321, 2008.

Lebensministerium: Planning Instruments, Lebensministerium, available at: http://wasser.lebensministerium.at/article/ articleview/50515/1/14408, last access: 17 January 2011.

Maldon District Council: Application 06/01035/FUL available at: http://myplan80.maldon.gov.uk/Planning/lg/GFPlanningSearch. page, last access: 19 December 2010.

Maldon District Council b: Final Committee Report 15/08/07, available at: http://myplan80.maldon.gov.uk/Planning/lg/ GFPlanningDocuments.page, last access: 19 December 2010.

Mitchell, J.: European River Floods in a Changing World, Risk 
Anal., 23(3), 567-574, 2003.

Nowak, J.: Inspectors Recommendation and Decision, 195322.pdf, available at: http://www.communities.gov.uk/documents/ planning-callins/pdf/195322.pdf (last access: 17 July 2010), 2006.

Osbaldwick Parish Council, Meadlands Area Residents' Association and Temple Avenue Residents' Association: Summary of the Objections to the Outline Planning Application by the Joseph Rowntree Housing Trust, report 227251 pdf, available at: http: //planningdocs.york.gov.uk/WAM/showCaseFile.do?action= show\&appType=planning\&appNumber=03/02709/OUT, last access: 10 July 2010, 2005.

Parliament of the Czech Republic: 254 Act on Water and Ammendements to Some Acts (The Water Act), 2001.

Peter Brett Associates: Flood Risk Assessment: Application Forms pdf 750115, available at: http://www.rbwm.gov.uk/ pam/planning_application_search.jsp?appnum=06\%2F01347\% 2FFULL, last access: 13 July 2010, 2006a.

Peter Brett Associates: Consultee Comments - General pdf 503990, available at: http://www.rbwm.gov.uk/pam/planning application_search.jsp?appnum=06\%2F01347\%2FFULL, last access: 12 July 2010, 2006 b.

Pottier, N., Penning-Rowsell, E. C., Tunstall, S. M., and Hubert: Land-use and flood protection: contrasting approaches and outcomes in France and in England and Wales, Appl. Geogr., 25, 1-27, 2005.

Reiner Böhm, H., Haupter, B., Heiland, P., and Dapp, K.: Implementation of Flood Risk Management Measures into Spatial Plans and Policies, River Res. Appl., 20, 255-267, 2004.

Rose, M.: Application form pdf 750113, available at: http://www.rbwm.gov.uk/pam/planning_application_search. jsp?appnum=06\%2F01347\%2FFULL, last access: 12 September 2010, 2006.

Royal Borough of Windsor and Maidenhead: Planning Application: Application Form (pdf 750376), available at: http://www.rbwm.gov.uk/pam/planning_application_search.jsp? appnum $=06 \% 2 \mathrm{~F} 01430 \% 2 \mathrm{FFULL}$, last access: 5 August 2010, 2006.

Ruimte voor de Rivier: available at: www.ruimtevoorderivier.nl, last access: 17 January 2010.

Runnymede Borough Council: Planning Application Form, Application ID RU.04/1050 available at: http://ww2.runnymede.gov. uk/home/latest/wklyplanapps/2004/wk39/1050f.pdf, last access: 20 September 2010, 2004.

Saxon State Ministry of the Interior: Preventative flood management measures by spatial planning for the Elbe river basin; Results and proposed actions, Freistaat Sachsen, Dresden, 2006.

Share, J.: Application form pdf 750113, available at: http://www.rbwm.gov.uk/pam/planning_application_search. jsp?appnum=06\%2F01347\%2FFULL, last access: 12 September 2010, 2006
Simeonova, V. and van der Valk, A.: The Need for a Communicative Approach to Improve Environmental Policy Integration in Urban Land Use Planning, J. Plan. Lit., 23, 241-261, 2009.

Skinner, N. C.: Community Comments pdf 750465, available at: http://www.rbwm.gov.uk/pam/planning_application_search. jsp?appnum=06\%2F01347\%2FFULL, last access: 12 September 2010, 2006.

Smith, K.: Community Comments pdf 503795, available at: http://www.rbwm.gov.uk/pam/planning_application_search jsp?appnum $=06 \% 2 \mathrm{~F} 01347 \% 2 \mathrm{FFULL}$, last access: 12 September 2010, 2006.

Ten Brinke, W. B. M., Saejis, G. E. M., Helsloot, I., and Van Alphen, J.: Safety chain approach in flood risk management, $\mathrm{Mu}-$ nicipal Engineer, 161(ME2), 93-102, 2008.

Tewdwr-Jones, M.: Spatial Planning: Principles, Practice and Cultures, Journal of Planning and Environment Law, 55, 560-569, 2004.

Thompson, L. L.: The Mind and Heart of the Negotiator, 3rd edition, Prentice Hall, London, 2005.

Tucasa: 40.000 edificios corren riesgo de inundación en España, available at: http://press.tucasa.com/noticias/ unos-40000-edificios-corren-riesgo-de-inundacion-en-espana/, last access: 20 July 2011, 2010.

Tunstall, S., McCarthy, S., and Faulkner, H.: Flood risk management and planning policy in a time of policy transition: the case of the Wapshott Road Planning Inquiry, Surrey, England, J. Flood Risk Manage., 2, 159-169, 2009.

Ury, W., Fisher, R., and Patton, B.: Getting to Yes: Negotiating Agreement Without Giving in, 2nd Edn., Penguin USA, 1991.

Watson, R.: Appeal General pdf 11094091, available at: http://www.rbwm.gov.uk/pam/planning_application_search. jsp?appnum $=06 \% 2 \mathrm{~F} 01347 \% 2 \mathrm{FFULL}$, last access: 20 October 2010, 2008.

White, I. and Howe, J.: Flooding and the Role of Planning in England and Wales: A Critical Review, J. Environ. Plann. Man., 45(5), 735-745, 2002.

White, I. and Richards, J.: Planning Policy and Flood Risk: The Translation of National Guidance into Local Policy, Planning, Practice and Research, 22(4), 513-534, 2007.

Wildsmith, D.: Report to the Secretary of State for Communities and Local Government: Appeal General (pdf 11060937) available at: http://www.rbwm.gov.uk/pam/planning_application search.jsp?appnum $=06 \% 2 \mathrm{~F} 01430 \% 2 \mathrm{FFULL}$, last access: 21 August 2010, 2008.

Woodhouse, J.: Consultee Comments (pdf 79518) available at: http://www.rbwm.gov.uk/pam/planning_application_search. jsp?appnum $=06 \% 2 \mathrm{~F} 01430 \% 2 \mathrm{FFULL}$, last access: 3 October 2010, 2009.

Wynn, P.: Development Control and Flood Risk Analysis of Local Planning Authority and Developer Approaches to PPG25, Planning, Practice and Research, 20(3), 241-261, 2005. 